Historic, Archive Document

Do not assume content reflects current scientific knowledge, policies, or practices. 



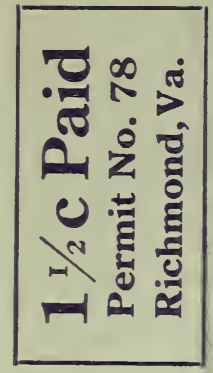
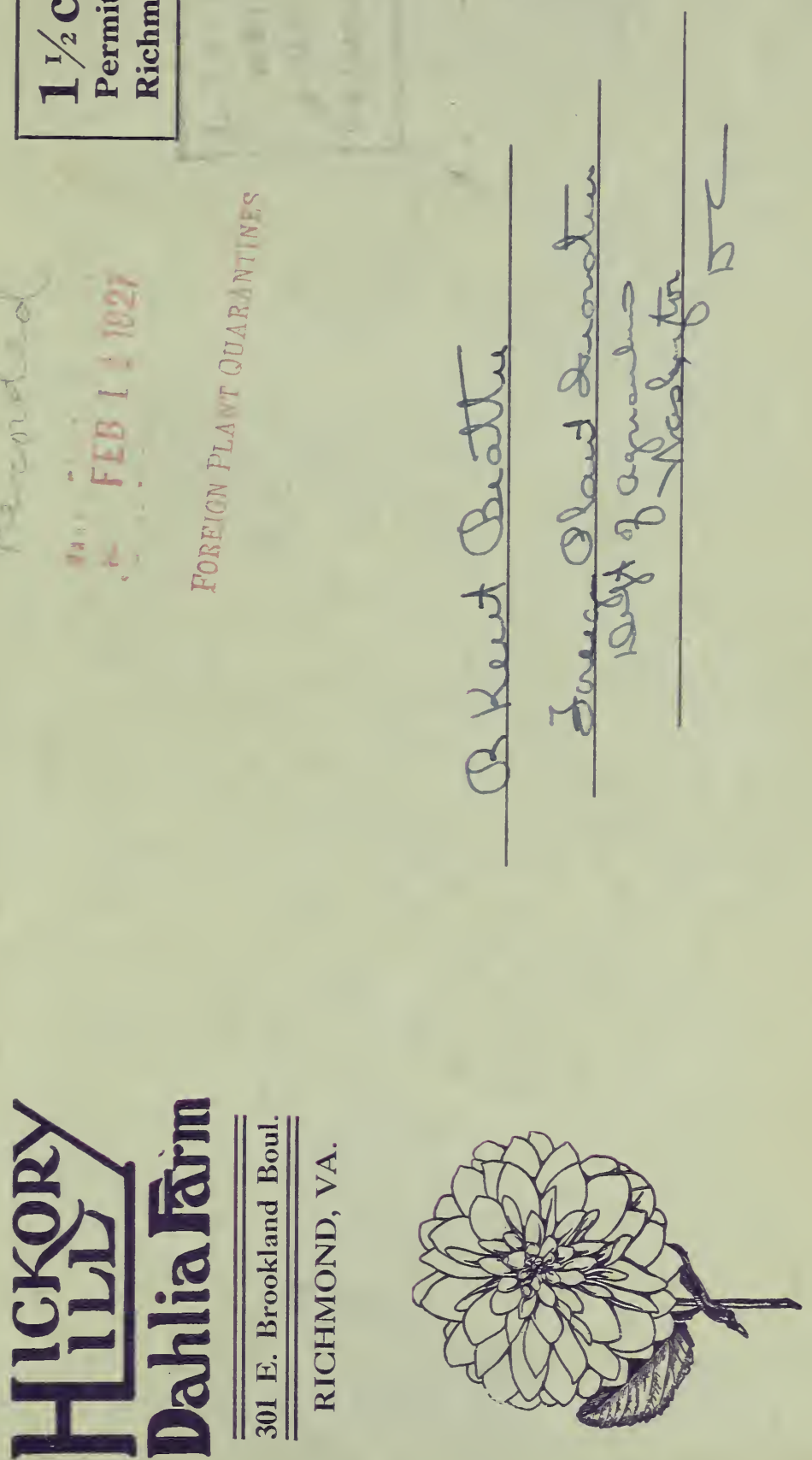



\section{New Dahlias}

Adda Patterson (Kemp) (HyCac). One of the best white. Averages 9 inches. Tall plant. Stems 4 feet long. Splendid keeper

Alaskan Yukon (Greinberg) ( $\mathrm{HyCac}$ ). Clear lemon yellow. Huge flowers on fine stiff stems. An excellent keeper

Avalon (Dec.). Pure clear yellow. Very large flower.

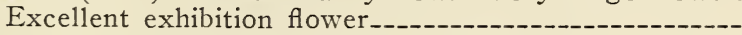

Bertha Jost (Jost) (Dec.). Base sulphur yellow, outer petals blending with peach pink, center tinted burnt orange. Very large flower.-.--

Casper G. Ware (Dahliadel) (Dec.). Clear violet rose. Flowers average 9 inches. Excellent keeping qualities.

Charles Stratton (Stratton) (Dec.). Pale gold, shaded and blended with old rose. Grand exhibition flower. One of the largest.

Elberon Beauty (F. \& M.) (HyDec.). Soft apricot, shading to a slightly darker tone at the center. Large exhibition flower

Elite Glory (Kennedy) (Dec.). A monstrous flower of red without any purple or maroon. Blooms and foliage gigantic in size. Especially fine keeper

Elkridge (Griffiths) (Dec.). Pure white. Flowers are of good size on splendid stems. Excellent for keeping when cut

Faith Garibaldi (Boston) (Dec.). Deep rose, shading lighter on the outer petals. Great depth, as well as large size. Profuse bloomer and early

Fort Washington (Dec.). Mahogany red, almost bordering on a maroon tinged with black, easily grown. 12 inches. Sturdy growth, free flowering-

Harrt Sheldon, Jr. (Murphy) (Dec.). White center with outer row of petals a shell pink, large flower, profuse bloomer

Herald Tribune Elite (Kennedy) (Dec.). Pure white. Splendid form and wonderful keeping qualities. Large flower

Lyndora (Hall) (Dec.). Medium yellow with a suffusion of Amaranth pink on the reverse. Very large. Ideal form. Long wavy petals, showing some pink at ends_- 10.00

Margaret Woodrow Wilson (F. \& M.) (Dec.). Opalescent pink. Face of petals creamy white with reverse phlox pink. Petals are broad and sharply pointed. Tremendous blooms

Marmion (Tyler) (Dec.). Golden yellow with a bronze suffusion on reverse of petals. Petals outlined bronze. Florets are long wavy and curl. Enormous size.-.---

Miss Bridgeton (Venable) (Dec.). Deep pink with a suffusion of violet. Large blooms on good stems 
Nagels Wonder (Cac). Scarlet, lightly tipped and marked yellow. Petals are long and narrow, more or less tubular. Tips cleft.-.-_.--

Nagels Roem (HyCac). Naples yellow tinted with salmon and chamois. Immense flowers on very rigid stems. Finest from Europe for years

Primulus Rex (Broomall) (Dec.). Very light cream or primrose yellow. Flower easily grown 10 inches. Profuse bloomer

Virginia Harsh (Broomall) (Peo.). Shell pink, one of the largest of its type. Petals are very wide and center ones are set straight out to front.

\section{General List of Dahlias}

Albert Ward (M. \& S.) (Peo) Light rosaline purple at tips of petals, shading darker at base. Free bloomer. Exceptionally large flowers

Alex Waldie (Broomall) (Dec.). Creamy ground color overlaid with pure salmon pink. Very large flowers on fair stems

Alice Voisinet (Davies) (HyCac). Copper rose with a tan reverse. Large flowers on medium size plant with purple green foliage

Amanda M. Greinberg (Greinberg) (HyCac.) Dark crimson. Very large flower with broad loose petals_.-----

Amanda M. Houghton (Slocombe) (Dec.). Lilac pink, changing to a soft pink toward the center, the center petals fading to pink white, tipped and suffused rose. Exceptionally large flowers. Ideal for exhibition work.-

Ambassador (Broomall) (Cac.). Soft yellow center with salmon, amber and pink shadings, gradually deepening toward the tips. Flowers average 8 inches, set stiff on the best of stems. Strong grower and free bloomer from early to late.-.-.--

Ami Barilett (Min). Deep scarlet. Flower under 2 ins.

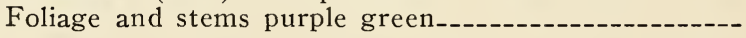

Amun Ra (Seal) (Dec.). Center petals are shades of copper and orange shading to gold and amber,deepening to a rich reddish bronze with a metallic lustre. Immense blooms easily grown to 8 inches on erect stout stems.

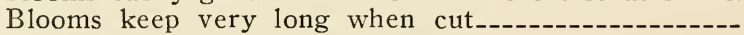

Ariel (Brown) (Pom). Buff. Tinted orange------------

Attraction (Hornsveldt) (Cac.). Clear lilac rose or orchid. Large elegant flowers. Habits are perfect. Long strong stems. Early and a very profuse bloomer. Bushy plants. Roots are rough looking and keep very poorly 
Aurora B (McWhirter) (Dec.). Royal purple dusted with silver, filled with contrasting collarette petals. Flowers averaging 5 inches on an excellent stem.

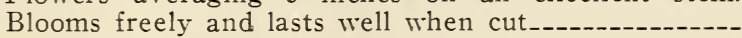

Ayesha (Maytrott) (Dec.). Sulphur yellow. Medium to large size blooms. Extra long, stiff stem. Profuse bloomer. Tall plant.

Azalea (Bruant) (Dec.). Soft creamy yellow, outer row of petals tinted pink creamy yellow, more or less suffused salmon, shaded to old rose. Bloom is formed of many rows of long, narrow florets. Average size

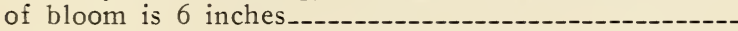

Ballet Girl (Boston) (Cac). Orange with white edge; white shading to orange; white edged orange and other variations. Very large flowers, averaging 7

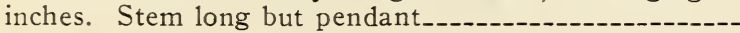

Baltimore (Vincent) (Dec.). Lemon yellow. Broad petaled medium size flower on good stems. A profuse bloomer

Bashful Giant (Marean) (Dec.). Apricot with golden shadings. Enormous flower easily grown to 9 inches. Stiff stem but pendant head. Ideal for exhibition.----

Ben Wilson (Murphy) (Dec.). Rich velvety red with each petal tipped yellow. Easily grown to 8 inches without disbudding. Excellent growing habits. Medium size plant

Berchuse (Boston) (Dec.). Salmon without a touch of yellow, changing to salmon suffused gold. Petals of medium width with a slight inward roll. One of the earliest to bloom. Very profuse. Flowers are about 6 inches on excellent stems

Bessie Boston (Boston) (Dec.). Deep scarlet, cleft petals

Biltmore (Stillman) (Dec.). Ground work is carmine and the petals are more or less tipped white. Flowers average 6 inches without disbudding. Very stiff stems.

Black Top (Superior) (Dec.). Dark velvety crimson with a darker center. Habit of growth, shape of flower and stem is identical to Millionaire. Easily grown to 9 inches

Bob Pleusse (Superior) (HyCac.). Carmine shaded to oxblood red, petals tipped white. Large incurved flowers

Bonnie Brae (Broomall) (Dec.). Cream shaded blush pink. Blooms are about 7 inches and very deep. Stems a little pendant at times because of the weight

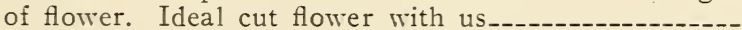

Boston White (Murphy) (Cac.-Dec.). White. Immense blooms. Can be forced to almost any reasonable size. Duplicate of Polar Bear, but has a better stem.---.--

Break O' Day (Maytrott) (Dec.-Cac.). Delicate clear sulphur yellow; shaded to light green yellow. Full high centers with back petals coming through the front ones. Excellent cut flower. Average size 5 inches. The center bud must be taken out instead of the two side ones...-...-...- 
Breezlawn (Maytrott) (Dec.). Vermillion. Perfect form with good full centers. Bloom averages 8 inches. Stems are inclined to be short at first.-.

Brunette (Pom.). Crimson showing white--------------

Cadiz (Boston) (Dec.). Reddish orange shading to chrome yellow at the base of the petals with a reflex of pale gold. Petals twist and turn. Profuse bloomer on splendid stems

Calvin Coolidge, Jr. (Root) (Dec.). Rose pink suffused salmon shading deeper toward the center while the petals are distinctly edged gold. Flowers are immense and never show an open center

Carmencita (Boston) (Dec.). Buttercup yellow striped sunset red. Huge blooms on stiff stems. Excellent keeper when cut. Sometimes all yellow

Catherine Wilcox (Marean) (Dec.). White tipped reddish pink. Heavy massive bloom being very full with thick petals. Blooms average 7 inches

Chancellor (Wilmore) (Peo.). Copper bronze with a reverse of oriental red. Petals are loosely arranged, curved and twisted. Easily grown to 8 inches without ciisbudding heavily. Stems are very long and somewhat pendant. Should be heavily staked

Chanson (Boston) (Peo.). Deepest lilac with a bluish sheen. Petals are very numerous, broad and flat. Tremendous blooms on satisfactory stems

Charm (Marean) (Dec.). Golden orchre, shading to burnt umber at tips. Large, perfect blooms on stout, wiry stems. Very free bloomer. Tall bushes.--_---------

Chickahominy (Bosher) (Dec.). Maroon copper. Plant habit excellent. Good keeper. Profuse bloomer on long stems. Dark green foliage. Blooms average 7 inches

Christine Evers (M. \& S.) (Peo.). Lavendar rose, reverse of petals showing a rhodamun purple, shading lighter at tips. Ends of petals curl, showing the two colors. Huge blooms. Stems 2 to 3 feet long--------

Cigarette (Boston) (Cac.). Creamy white, heavily edged orange, but no two alike. More vividly colored than Ballet Girl. Petals are long and narrow and are inclined to curl slightly. Bloom is very large and of

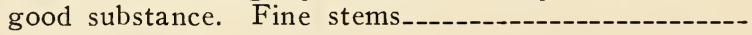

City of Portland (Gill) (Peo.). Deep nut yellow. It has every good quality. Immense flowers. Long, strong upright stems. Flants are strong and vigorous and produce blooms very freely

Comstock (Boston) (Dec.). Yellow. Immense flowers with petals slightly fluted.---_-

Dakota (Marean) (Dec.). Deep tone of coral red suffused copper. Six-inch blooms on stiff, strong stems. A very vigorous bloomer 
Dardenella (Varra) (Dec.). Scarlet red and golden yellow, base and larger part of petals are red and the tips are shaded to yellow. One of the best. Average size of flower is 7 inches, but it can be forced to 10 inches. Stems are long and very thin. Profuse bloomer

Darkeye (Boston) (Dec.): Flesh pink with the petals, especially the center ones, heavily edged lavender. Lavender color nearly disappears in the late season. Huge thick blooms on very stiff stems. Petals are sometimes slightly quilled. Six-inch blooms..-...-.-.

Delighted (Childs) (Show). White. Exceedingly large flowers for its type. Center is slightly elongated. Very profuse bloomer

Delice (Charmet) (Dec.). Rose pink. Ideal florist flower, but a very slow bloomer-.-.--..--

Dorothy Wooten (Hathway) (Dec.). Rose pink. Medium size blooms on fine stems. Very good cut flower.

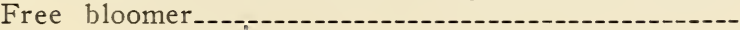

Dream (Hornsveld) (Dec. Peo.). Peach pink with an amberlike glow. Perfect form, standing erect on long stems. Ideal for cutting. Very broad petals..--.-.---

Dr. H. L. Tevis (Pelicano) (Dec.). Salmon rose suffused old gold and shaded to apricot. Flowers are easily forced to 9 inches. Excellent cut flower on good stem

Dr. L. C. Bosher (Bosher) (Dec. Cac.). Reddish salmon pink, the so-called Henna. Heavy petals are slightly twisted. Excellent for cutting. Blooms average 7 inches -.---

Drum Major (Dreer) (Peo.). Fiery red, which is intensified by a lemon yellow center with which the petals are more or less tipped and marked. One of the largest of the peony type. Under ordinary field cultivation

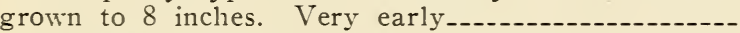

Earl Williams (Doolittle) (Dec.). Crimson scarlet with each petal marked and tipped white. One of the largest with out disbudding. Very early and very prolific.

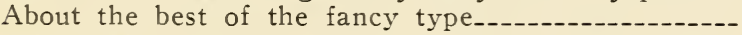

Eastern Star (Maytrott) (Dec.). Soft saffron yellow with old gold shadings. Flowers are of great substance and good keeping qualities. Full center. Excellent bush growth and free flowering. Easily grown

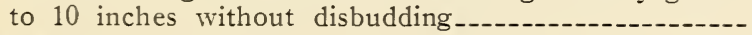

Eagle Rock (Broomall) (Dec.). Creamy white, shaded apple blossom pink. Large massive flower. In some localities it approaches the show type in form. Plants very dwarf

Edith Wooster (Boston) (Peo.). Tea rose, blend of red and yellow; yellow is overlaid and suffused sunset red. Very large, thick blooms. Free flowering with excellent habits

El Camino Real (Dec.). Spanish crimson, large and full

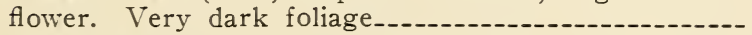

Eliza Clarke Bull (Boston) (Dec.). Pure white. Very large and regularly formed. Stood extreme heat and drought of last season without burning a single petal. Bushes of medium height. Profuse bloomer...-...-. 
Emil Panuski (Rodeck) (Show). Light lavender ground striped maroon occasionally sporting to a solid maroon. Form is perfect and of the largest size. Grown on

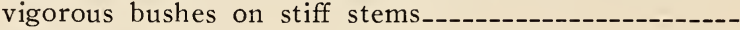

Emma Marie (Dahliadel) (HyCac). Clear pink with a creamy white center half. Robust grower. Flowers average 8 inches on long stiff stems

Emperor (Marean) (Dec.). Deep royal purple. Long, flat petals. Color does not spot under adverse weather conditions. Enormous blooms on extra stiff stems. Perfect form and habit. Very tall bushes

Epworth Glory (Bosher) (Dec.). Canary yellow, more or less tipped white. A lighter yellow than Exmouth Glory, of which it is a sport. Large flowers on very long stems. Bushes tall. Great many blooms come pure white

E. T. Bedford (Marean) (Dec.). Purple, shaded lighter on edges of petals. Blooms easily measure 10 inches without forcing. Very profuse flowering --_-_-_----

Etendard De Lyon (Ferard) (Cac. Dec.). Royal purple. Blooms average 6 inches. One of the most prolific. Very stiff but slender stems.-.-.-.--

Eva Williams (F. \& M.) (Dec.). Amethyst (197) with silver shadings. Excellent exhibition flower. Full center at all times. Stems very rigid. Free bloomer----

Fascination (Alexandria) (Pom.). Pink lavender--------

Florence Michell (Root) (Dec.). Cream white with a faint suffusion of shell pink. Full centered all season. Petals are long and pointed. Bush growth excellent. Wonderful exhibition flower-.---.--

Frances Lobdell (Waite) (Cac. Dec.). Pale Amarinth pink with center white, changing to Marguerite yellow. Habits excellent. Stems are rigid and very long. Blooms average 6 inches and 3 inches deep. Tall plant.

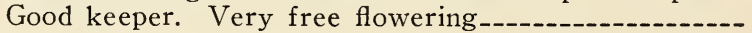

F. W. Fellowes (Stredwick) (Cac.). Orange. Blooms larger than usual for a Cactus type, growing in our field this season over 9 inches. Very sharp pointed petals

Gee Whiz (Broomall) (Cac. Dec.). Soft buff, shaded salmon. Seven-inch blooms 2 inches deep. Never shows an open center regardless of the weather. Good long stems

Geisha (Hornsveld) (Peo.). Buttercup yellow at base of petals, shading to scarlet toward the center of petals and passing lighter at tips. Petals are broad, loose and twisted snake fashion around the center. A very poor root producer and keeper. Huge flower on a long slender but slightly pendant stem.

Giant Ruby (Greinberg) (Dec.). Vivid red. Enormous flowers with full centers and on a good stem. Classed as the best red.

Gilda Gray (F. \& M.) (Dec.). Petals of pure lilac shading to a deep tyrian rose. Profuse bloomer. Huge bloom 
Gladys Sherwood (Broomall) (Cac. Dec.). White. Blooms are huge, being easily grown to 8 inches without disbudding. Finely formed blooms on cane-like stems. Weather has no effect on the flowers

Glory of Argonne (Maytrott) (Show). Persian lilac, shading to a white center. Perfectly formed 6-inch blooms on an 18-inch stem. Ideal cut flower-

Glory of New Haven (Slocombe) (Dec.). Orchid lavender. 8-inch blooms with broad, twisted petals on long stiff stems

Glory of Verdun (Dec. Show). Crimson shaded to bright vermillion

Goodby Delice (Broomall) (Dec.) Pink. Good size flower produced in utmost profusion. As a cut flower it is without a rival

Grace Marie (Varra) (Dec.). Alzarine pink, shading to eosine pink. Center petals are rose with cadmium yellow showing through the rose. Large, fine flower on good stems. Tery profuse bloomer-.--.---.----

Grace Sperling (Underhill) (Dec.). Face of petals golden buff and reterse of Amaranth purple. Huge blooms on good stems

\subsection{0}

Gretchen Heine (Alexander) (Pom.). White, tipped rose

Grisette (Hy-Cac). Old gold, hearily flushed with pink. Flowers are large and ideal in every way.............

Grizzley (Burns) (Dec.). Dark velvety maroon. Immense flowers are composed of broad petals, a little twisted at tips and slightly reflexed. Stem is orer 24 inches long. Best of its class

Halvella (MclWhirter) (Dec.). Old rose with a golden sheen. Great size and substance with good keeping qualities. Free bloomer on an excellent stem-..-...-.-

Henry F. Michell (Root) (Dec.). Blending of scarlet and red. Habits late. Blooms 7 inches wide by 3 inches deep. Unusually tall bush, reaching a height of 8 feet

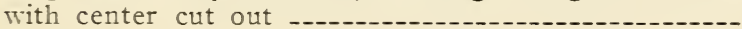

Herbert Raby (Mastick) (Cac.). Purple crimson. Petals are ,narrow and tubular and twisted like a spinning

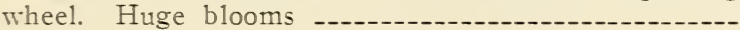

Hercules (Marean) (Dec.). Tangarine and deep yellow, reverse of the petals shaded tangarine. Quilled and of enormous size. Long, stiff stems. Exceptionally free bloomer

His Majesty (Boston) (Dec.). Bright scarlet. An immense bloom without much disbudding-...-.-.-.-.-.-.-

Hong Kong (Doolittle) (Peo.). Deep buttercup yellow toward the center; outer petals are shaded a deep tomato red. Immense blooms on very long and satisfac-

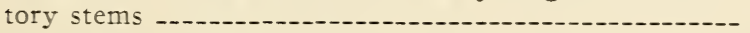

Howard Wright (Dec.). Mallow pink. A good size full

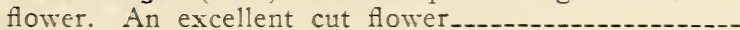


Insulinde (Kriest) (Cac. Dec.). Dull old gold, suffused bronze and dusted gold. Outer petals are twisted, showing the mauve tint on the reverse of the petals. Flowers grow erect on top of the stems.

Islam Patrol (Davies) (Dec. Cac.). Very dark velvet scarlet tipped and flushed with pure gold. Stands very upright on cane-like stems. Huge bloom.

Ismalia (Davies) (Cac. Dec.). Velvet maroon shaded to red. A very large flower with a perfect form on a perfect stem

James C. Gill (Gill) (Peo.). Golden orange marked scarlet. Appears to be salmon pink under artificial light. Extra long, strong stems. Free bloomer. Giant blooms. Medium sized plants. Five rows of large broad petals_

Jean Chazot (Cayeux) (Cac.). Golden bronze, heightened with a suffusion of nasturtium red. Faultless flower on a good stem. Free bloomer and an excellent keeper. Averages 8 inches

J. K. Alexander (Alexander) (Show). Violet purple. Large flower on a good stem.

John Lewis Childs (Boston) (Dec). Yellow suffused and striped and generally tipped white. Eight-inch blooms on stiff stems. Execellent keeper. Self-colored blooms are red tipped white

Jersey Beacon (Waite) (Dec.). Brightest of all so-called reds, with a tan reflex. A Dahlia without a fault. Grows to 12 inches

Jersey's Beauty (Waite) (Dec.-Peo.). Spinel pink slightly tipped gold; habits fair; stiff 24-inch stems. Seven inches in diameter. A prize winner everywhere exhibited

John Tozar (Maytrott) (Show). Bishops violet. Large perfectly formed flowers on extra long stems. Profuse bloomer all season

Joppa (Vincent) (Dec. Cac.). Dark salmon rose. Tall grower. Habits excellent. Seven-inch bloom on canelike stems. Easily keeps a week when cut_------------

Judge Marean (Marean) (Dec.). Salmon pink, orange, yellow and pure gold. Very large flowers. Perfectly true type. A most profuse bloomer. Long, straight stems. About the best bloomer in our field with one exception

Justice Bailey (Wilmore) (Cac.). Shell pink, shaded to white. Good size bloom. Flowers are in great profusion

Kalif (Englehardt) (Dec. Cac.). Pompeian red. Perfect form, being very deep and full. Large blooms on wiry stems

Kitty Dunlap (Boston) (Dec.). Shade of American Beauty rose. Blooms freely all season. Excellent keeping qualities. Long, firm stems. Immense blooms of good substance. Petals have a tendency to curl and are very broad. Long stems are practically without leaves.--- 
Kohinoor (Boston) (Dec. Cac.). Deep maroon and at times almost black. An immense deep bloom of true type. Petals roll closely and form a magnificent incurved flower. Blossoms very freely from early to

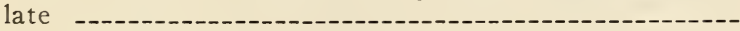

Lady Elizabeth (Totty) (Plume Cac.). Canary yellow overlaid bronze pink. Tips of quilled petals are split. Petals stand out straight

La Mascotte (Boston) (Dec.). Front of petals are silver white while the reverse is a deep violet.-.-.---.-----

Laura Weber (Weber) (Dec.). White, the finest and largest of its color. Huge bloom

Laura M. Starke (Bosher) (Dec.). Soft red with a white tip, the white extending part way down the center of each petal. Some blooms are pure scarlet. Blooms measure 6 inches as an average and are grown in great numbers on a medium size bush. Petals wide

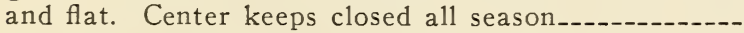

La Gros Bete (Marean) (Dec.). Dark cerese. Huge bloom. Excellent exhibition type as well as cutting

e Toreador (Marean) (Dec.). Crimson. Exceptionally free bloomer. Strong, wiry stems. Excellent keeper. Unrivaled for shipping

Lida J. Smith (Root) (Cac. Peo.). Center a deep maroon, almost black, outer petals magenta shading lighter toward the tips and striped a velvety brown. Large blooms, easily measuring 8 inches, and are held erect on strong but slender stems. Very early and, free bloomer

Little Jewel (Min Dec.). Peach blossom pink. Bloom

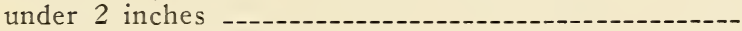

Long Island Sunrise (Show). Scarlet and gold. Unevenly divided

Mabel Thatcher (Marean) (Dec.). Pale yellow deepened to gold. Flowers average 8 inches on a strong, stiff stem. Very profuse bloomer

Madonna (Ware) (Hy-Dec.). Pale blush white. Blooms average 4 inches. Very profuse. Early bloomer. Especially good for cutting-

Maid of Mist (Slocombe) (Dec.). Deep cream, shading to a salmon pink. Outer petals rolled back to a depth of 4 inches, pointed and twisted. Easily grown to 10 inches

Maku (Boston) (Cac.). Shell pink. Graceful incurved petals. Color does not bleach in sunshine...-...-..-

Marion Christine (Howell) (Dec.). Cadmium yellow, tipped begonia rose. Excellent in every respect. Average size of blooms 6 inches

Mariposo (Boston) (Dec. Cac.). Pink intensified by violet. Long, narrow, incurved petals that twist and curl. Absolutely long, stiff stems over 3 feet. Blooms very early 
Martha Washington (Dahliadel) (Dec.). Maroon with a lighter reflex and tipped Tyrian rose. Huge blooms on a fine stem

Maybelle Eckland (Doolittle) (Peo.-Dec.). Maroon and wine shades. One of the finest of the dark shades. Tremendous flower. Unusually hardy variety of rich velvety texture

MacGregor (Mastick) (Dec. Cac.). Spectrum red, base of petals lemon yellow. Flowers are large and full and are carried on long, upright stems. One of the few that are not affected by pests. Excellent keeper.---.--

Meadow Lark (Seal) (Dec.). Buff and straw, with the reverse side of petals darker. Large flowers on long,

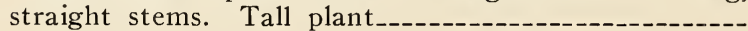

Medusa (Peacock) (Cac.). Rose red, tinting lighter at tips. Long narrow buds. Entirely new type. Narrow petals unroll with a twist. Petals reflex down. Flower easily grown to 8 inches.--_-_-_-_-

Merrick (Albright) (Cac. Dec.). Light maroon, tipped mahogany, reverse mahogany. Very large and a free bloomer on a fine stem

Merry Widow (Marean) (Dec.). Clear yellow, suffused red at edges of the petals. Enormous blooms produced on top of the stems. An extraordinary shaped flower

Millionaire (Stillman) (Dec.). Lavender, overcast with pink, sometimes tinted with white. Largest of its kind, being easily grown 8 inches without forcing. Very deep flower. Slow bloomer. Good root maker, but a very poor sprouter. Wide, flat petals. Never shows a center

Mina Burgle (Burgle) (Dec.). Geranium red. Petals are broad and flat. Excellent under artificial light.--------

Mme. Jules Galburn (HyCac.). Orange golden yellow and white. Flowers are large and resemble a chrysanthemum because of their twisted and quilled petals.--

Mme. Von Bijstein (Wouters) (Peo.). Lilac mauve. Tall plant with a stiff stem. Petals are very curly. Medium size blooms

Mohammed (Davies) (Dec.). Clear, soft yellow. Many of the flowers come peony in this climate. Blooms average 6 inches

Mordella (-) (Dec.). Bright apricot buff. Flowers average 9 inches. Petals are slightly pointed at the tips, making it look like a Hybrid in some localities. Excellent under artificial light. Long, graceful stems. Profuse bloomer

Morocco (ShowHy). Maroon with white tips. Large blooms for its type. Very profuse

Mr. Crowley (Broomall) (Dec.). Salmon pink, shading to a bright yellow, overlaid violet. Excellent keeper. Dwarf plant. Flower averages 6 inches. Must be heavily disbudded to make good flowers.-------------- 
Mrs. Carl Selbach (Selbach) (Dec.). Mallow pink, shaded lighter in center with each petal outlined with deep mauve. Seven-inch flowers on strong, stiff stems. One of the best of its color

Mrs. C. D. Anderson (Slocombe) (Show). Purplish crimson. Large blooms. Petals reflex forming a perfect ball. Excellent stems

Mrs. Charles Smithers (Dec.). Magenta purple suffused

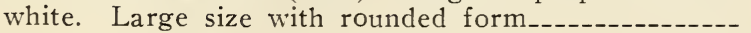

Mrs. Edna Spencer (Spencer) (Cac. Dec.). Lavender pink, shaded lighter. Great blooms on fine stems. Ex-

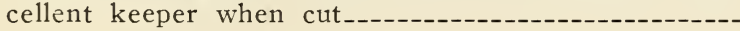

Mrs. E. F. T. Smith (Broomall) (Cac. Dec.). White with a lemon center. Largest of its kind. Profuse bloomer on strong stems --.---_-

Mrs. Eleanor Martin (Pelicano) (Dec.). Crushed mulberry, suffused gold and marked with two lines rose. Blooms average 9 inches on perfectly stiff stems over

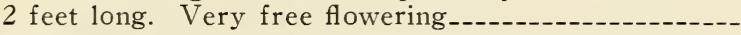

Mrs. Hugo Kind (Kind) ( $\mathrm{HyCac}$ ). Rich shade of velvety carmine reflex spectrum red. Flowers of medium size on long straight stem-_-_-_.--

Mrs. I. Devere Warner (Marean) (Dec.). Mauve pink or orchid. Large perfectly formed flowers. Good

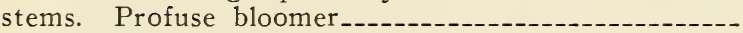

Mrs. John Bray (Boston) (Dec. Peo.). White ground striped and splashed with maroon. Large blooms. Habits exceptional

Mrs. Jessie Seal (Seal) (Peo.). Old rose with golden suffusion and shadings. Largest of its coloring. Long, stiff stems. Sturdy plants. Free flowering. Profuse bloomer

Mrs. John M. Root (Root) (HyCac). Immense flowers of pure canary yellow. One of the largest dahlias. Petals are long, broad and slightly twisted.

Mrs. John T. Sheepers (Marean) (Dec.). Center of clear canary yellow, gradually changing to a shade of pink on the outer edges. Huge blooms on very stiff stems.-

Mrs. Robert B. Stiles (Peacock) (Peo.). Light tyrian pink, tipped lighter with a reflex of true pink. Blooms average 7 inches and 3 inches deep. Cane-like stems 20 inches long. Strong, vigorous, sturdy grower. Re-

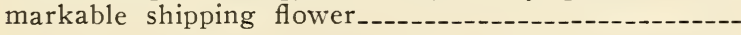

Mrs. S. G. Milosi (Babylon) (Dec.). First blooms red, then white with red center. Huge blooms on very stiff stems. Excellent for cut flower work-_-_-_-_-_-----

Mrs. Thomas Bush (Peacock) (Peo.). Reddish salmon, shaded to primrose and tipped rose. Exceptionally long stems. One of the most profuse bloomers grown. Excellent cutting flower

Myra Valentine (Mills) (Dec.). This tall growing variety produces large golden bronze flowers on two to three foot stems. Fine for exhibition or cutting 
Nancy Mae (Babcock) (Cac.). Carmine, shading rich reddish purple. Fine, large flowers. Good, erect stems. Excellent for cutting

Nerissa (Turner) (Pom.). Silver pink-_-_-_-_-_-_-_-_-

Nibelungenhort (G. \& K.) (Cac.). An old favorite, often measuring from seven to eight inches in diameter; of a violet rose suffused golden apricot. Very profuse

Nobilis (Doolittle) (Dec.). White with crimson markings. A sport of Earl Williams and in our opinion a better keeping Dahlia

Old Sol (Maytrott) (Peo.). Primrose yellow, shaded copper red. Seven-inch blooms on 20 -inch stems. Bloom when open forms a soft, full ball and does not show its center till the petals start to drop. Immune to bad weather -..--

Oregon Beauty (Gill) (Dec. Peo.). Oriental or geranium red. Free flowering on slender but wiry stems. Outer petals reflex to stem. Excellent cutting flower--------

Oregon Sunset (White) (Peo.). Golden yellow, heavily suffused bronzy crimson. Long, stout stemś. Free bloomer. Flowers easily average 8 inches----------

Osam Shudow (Boston) (Dec.). Delicate old rose. Slightly suffused lilac and shaded to yellow at the center. Big, heavy loose petals resembling a rose rather than a Dahlia. Blooms average 9 inches. Bush is very tall--

Our Country (Stillman) (Dec.). Deep purple and florets heavily tipped white. Very deep bloom with a closed center

Papillon (Boston) ( $\mathrm{HyCac}$ ). Old rose, tinted gold. An incessant bloomer. Stems long and very stiff. An improved Geo. Walters. Flowers average 7 inches without disbudding

Paradise Found (Doolittle) (Dec. Peo.). Deep lemon yellow. Giant double flower with fluted petals. Free in bloom and on good stems. Blooms ten to twelve inches and with a depth of seven inches

Patrick O'Mara (Vincent) (Dec.). Orange buff, tinted neyron rose. Huge stiff bloom on good stems. Splendid

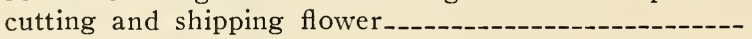

Paul Michael (Michael) (Dec.). Gold or orange buff shaded to old rose. Average size of bloom 9 inches. Petals curled, twisted and pointed. One of the most prolific of all Dahlias

Peacock (Peacock) (Dec. Show). Finest variegated maroon purple, edged white. Wide petals. Dwarf bush; full deep centers

Peppermint Candy ( $\mathrm{HyCac}$ ). Creamy white with many crimson stripes and splashes. Very large size and a very free bloomer. Stem slightly pendant.-...-..--.-- 
Perfect Beauty (Stillman) (Dec.). Bright light scarlet, outer ends of petals heavily tipped white. Colors are divided ahout equally. A most beautiful flower of large size.-

Pond Lily (Sherk) (Dec.). The flowers, which are of good size, face directly upwards, and are on extra good stems. The color is pink suffused with purple. The formation of the flower resembles a pond lily. It is a free bloomer and has fine foliage. The flowers come out early in the season and keep up until frost.--------

Pop Stewart (F. \& M.) (Dec.). Petals are rosy pink, maturing to a lilac pink. Remarkable flower of great size

President Wilson (Jones) (Dec.). Vermillion, scarlet tipped white. Some flowers are self-colored. Petals are long and pointed. Huge blooms on fair stems. A poor root maker and poorer root keeper

Pride of California (Lohrman) (Dec.). Crimson red with a darker center. Huge flowers on long, straight stems. Free grower. One of the best reds for all purposes. An excellent keeper

Pride of Connecticut (Alling) (Dec.). Amarinth pink, blending tyrian pink, edge of each petal rose pink. Plants are of medium height. Stems are 12 inches long in clear. Flowers average 7 inches and 2 inches deep. An excellent keeper

Pride of San Francisco (McWhirter) (Dec.). Golden salmon pink. Six to seven-inch flower on stout stems. Habits excellent. Requires no staking or disbudding--

Pride of Wayne (Greinburg) (Dec.). Plum purple. Flowers are of enormous size on excellent stems. Fine for exhibition purposes

Queen Dido (Dec.). A shade between tyrian rose and mallow pink. Large flower on long stems..--..--..-

Queen Zenobia (Archer) (Cac. Dec.). Pansy purple with a lavender reverse. Petals twist showing the two colors. Tall grower with scant foliage. Seven-inch

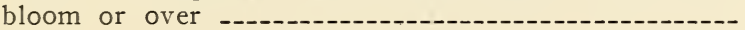

Red Devil (Finger) (Dec.). Carmine and nopal red, tipped and suffused golden yellow. Large thick bloom on heavy, medium length stem. All blooms in 1925 were solid color

Red Wing (Kirby) (Dec.). Scarlet. Exceptionally good growth and stem. Fine cut flower. One of the best

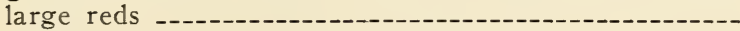

Rodman Wanamaker (Peacock) (Dec. Peo.). Buds are pale lemon yellow as it first expands, but it quickly develops into a golden yellow bronzy salmon pink and flnally into a beautiful shade of ochraceous salmon with a reflex of spinal pink. Originator says, "It is the largest Dahlia grown." Blooms here average 9 inches without disbudding. Plant is a giant, strong, sturdy and vigorous. Lacelike foliage. 
Roman Eagle (F. \& M.) (Dec.). Burnished copper. Large flower. Medium size plants.--_-_-_-_-_-_-_-_---

Rookwood (Boston) (Dec.). Cerise rose, without the faintest touch of magenta. Flowers are immense with good depth on straight stems. Bushes grow low and are always covered with bloom

Rory O'Moore (McWhirter) (Dec.). Violet purple, heavily tipped white, petals being violet and edged white. Blooms are very large and plants are very free flowering

Rotarian (Vincent) (Dec.). Velvety maroon. Large curled and twisted petals. Profuse bloomer. Erect, good habit of blooming and growth. Form is like the emblem of that name.

Rumson (Waite) (Dec.). Beautiful soft pastel apricot. Blooms of good size on excellent stems and full at center. Fine for cutting-

Sagamore (Bedetty) (Dec. to Peo.). Golden yellow on the outside petals and shading to a golden salmon. Flowering habit free. Ships well. Blooms average 8 inches by 3 inches deep. Strong, wiry stems

Sammie (Maytrott) (Dec.). Primrose yellow. Excellent form on extremely long, stiff stems. Petals slightly reflexed. Six-inch flower

Sanhican Bluebird (F. \& M.) (Dec.). Outer petals at maturity are bright violet blue, while the center ones retain the violet tint, making it the nearest to a blue Dahlia. Blooms are of gigantic proportion and are perfect in form. Strong, wiry stems

Sanhican Darky (F. \& M.) (Dec.). Bordeaux crimson, almost black toward the center, the whole covered with a chocolaty sheen, margins of petals marked Amaranth purple. Huge ideal exhibition flower------

Sanhican Gem (F. \& M.) (Dec.). Old rose thickly suffused with amber in its young state, at maturity it is clear old rose. Giant flower. Petals are large and thickly placed, being a true staghorn type of flower--.-------

Senorita (Lohrmann) (Dec. Cac.). Dark maroon; giant flower; dwarf plants. Stems are long and very stiff--

Sensation (Single). Red with petals striped or tipped or tipped white. Very profuse---_----------------

Sheba (Peacock) (Dec. Peo:). Petals tipped white, a broad band of white along the middle toward the base, both edges cardinal darkest on opening petals. Fluffy, loose and stylish. Petals recurved, twisted and whirled. Some half spiral edges, some inrolled trowel like, the tips acuminate, none of them cleft. Blooms facing on perfect stems well above the foliage-----------------

Shirley Brown (McWhirter) (Dec. Cac.). Old gold, tinting salmon; very large flowers, on long, wiry stems. Excellent for exhibition purposes 
Siskiyou (Broomall) (Dec. Cac.). Pink, tinted mauve. Plants are sturdy and vigorous and flowers are held erect on extra long and sturdy stems. One of the largest of all, easily grown $11 \frac{1}{2}$ inches in this locality.

Sou De G Doazon (Bruant) (Dec.). Orange red. An old established favorite. Huge blooms always full to center. Plant is tall with heavy dark green foliage. Long, stiff, upright stems

Snowdrift (Broomall) (Dec.). White. Immense deep flowers. Very broad and wavy petals. Blooms open quick$1 y$ and remain for a week. It never sunburns and when the last petal drops it is as white as when it first opens

Sulphuria (West) (Dec.). Sulphur yellow. Large, long petals half quilled upward and bent backward. Dwarf

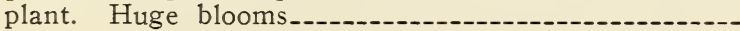

Sunny Jersey (Maytrott) (Dec.). Lemon yellow suffused gold. Especially free bloomer. Petals are broad and flat and are inclined backward. Large flower.......-.

Swastika (F. \& M.) (Peo.). Coral pink with golden sheen.

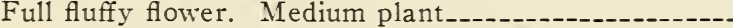

Syria (Davies) (Dec. Cac.). May rose and canary, striped and splashed with dark cardinal. An absolutely true Hybrid type. Large blooms on good stems

Talisman (Boston) (Cac). Brownish red, with a reverse of tan. Petals are long, incurved slightly and open at the tips showing the reverse color. Huge flower.--

Tehachepi (Broomall) ( $\mathrm{HyCac}$ ). Canary yellow, very large flowers on fine stems. Sometimes called Yellow Gladys Sherwood

The Bandit (Reed) ( $\mathrm{HyCac}$ ). Mahogany red and pure gold. Narrow petals that curl and twist showing the

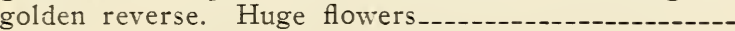

Theodore Vail (Boston) (Dec.). Old gold, shaded to apricot. Stem is long and very straight. Very large and heavy flowers

Tillamook (Broomall) (Dec.). Canary yellow. Huge blooms easily averaging 8 inches. Excellent habits. Considered to be the finest decorative yellow produced

Tommy Atkins (Boston) (Dec.). Flaming metallic scarlet (No. 85) shades (4). Large, deep blossoms. Center remains closed all season. Stems stiff as cane. Blooms freely, is very free and continuous

Tryphinnie (Estes) (Dec). Bright shell pink, shading lighter at the tips of the petals, bright golden yellow at the base of the petals. Perfect bloom on very long, wiry stems

Uncle Henry of $\mathrm{Oz}$ (Doolittle) (Dec.). Cerise rose. Very tall sturdy plant. Good size bloom on long stems...-.- 
Uncle Sam (M. \& S.) (Peo.). Orange buff at base of petals shading to bitter-sweet pink at tips, all overlaid golden sheen. Center petals mustard yellow streaked with deep rose pink. Petals are curled and twisted. Immense blooms easily grown to 10 inches without disbudding. Stiff stems over 3 feet long

U. S. A. (Stillman) (Dec. Cac. Peo.). Deep salmon-orange. Blooms average 7 inches. Petals are twisted slightly and the back rows are pushed through the front ones. Excellent formation on extra good stems.

Venus (Marean) (Dec.). Creamy white with a lavender suffusion. Large flowers. Pointed and incurved petals. Profuse bloomer

Verdun (Cazeon) (Cac.). Yellow, tipped and edged white. Exceptionally stiff stems. Large size bloom--.-------

Vineland (Maytrott) (Dec.). Russet orange suffused apricot. Petals curl and twist; bloom is of immense size. Similar to Mrs. G. W. Elkins, but heavier and better color. Good keeping qualities

Violetta (Rivori) (Cac. Dec.). Petunia violet. Large flowers on upright stems

War Dance (Gill) (Dec. Cac.). Color is similar to Geisha, except it is scarlet tipped and marked golden yellow. Gigantic flowers, often 10 inches, being very heavy and massive; carried on good stems. Strong, vigorous plants, producing an abundance of fine flowers.......--

W. Darcy Ryan (Boston) (Dec.). Violet purple, heavily shaded white. Never has a self-colored bloom. Large flower on a good stem. Very free bloomer..--...--

Whiffestan (Doolittle) (Dec. Peo.). Pure white. One of the best of its color. Often grows over 10 inches, being an average of 7 inches

Winifred Slocombe (Slocombe) (Dec.). Mustard yellow at tips and shaded to mikado yellow at center. Blooms average 7 inches by 2 inches deep. Dwarf plant.-----

Wizard of $\mathrm{Oz}_{\mathbf{z}}$ (Doolittle) (Dec.). Amber pink or soft salmon pink. Easily grown to 10 inches and can be forced to 14 inches. One of the finest grown. Apparently has no fault

W. W. Rawson (Rawson) (Show). White flushed and shaded amethyst, center amethyst. Stems are erect and very heavy. Good size flower. Excellent for cutting purposes

Yale (Alling) (Dec.). Base is for the most part deep violet purple with a deep and distinct edging of pure white. Stem is very long and has tendency to droop.-

Yellow King (Hornsveldt) (Dec. Cac.). Light yellow. Exact shape as Attraction, but different color. Large elegant flowers on long, wiry stems. Excellent cut flower. Clumps hard to divide in the spring 


\section{A Few Jerseys}

Jersey's Caprice (Dec.). Autumn shades. Flowers are large and of good form and substance. Stems are rigid, holding the blooms erect. Splendid variety for exhibition or cut flowers

Jersey's Delight (Dec.). Old rose pink. Flowers are large and are borne on good stems. Foliage leathery in texture and a good insect repeller

Jersey's Elegans (Dec.). Spinal pink or deep rose. Flowers are of medium size, produced freely on straight, upright stems. The foliage is finely cut and rough in texture, therefore it is not affected by leaf hopper

Jersey's Empress (Dec.). Anthracene violet. The flower, which is very large, has a very pleasing formation. The petals are narrow and wavy. The flowers have great depth and good substance, and they have no tendency to burn or fade with the sun_.........-.-.

Jersey's Gem (Dec.). Lavender pink. Flowers are large and produced on perfect stems. It is very prolific and is a splendid cut flower...............-

Jersey's Ideal (Dec.). Lavender pink, although it varies to phlox pink. Flowers are very large and of great depth. It is a vigorous grower with large leathery stems, being almost insect proof

Jersey's Jewel (Dec.). Soft lavender pink. Tery large flower. Long pointed petals. Without disbudding flowers average 9 inches

Jersey's King (Dec.). Begonia rose. Large, broad petaled flowers on splendid stems

Jersey's Mammouth (HyDec.). Rich golden mahogany. This is not a good cut flower, because of its enormous size. Easily grown to 10 inches, frequently.

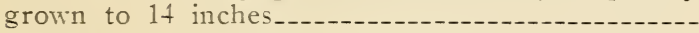

Jersey's Monarch (Dec.). Deep salmon with yellow at the base of the petals. Very large blooms and very deep on long, stiff stems

Jersey's Pride (Dec.). Apricot orange, with golden suffusion. A very large attractive flower produced

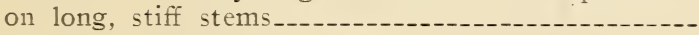

Jersey's Rose (Dec.). Paul Neyron rose shade. Fine stiff stems and insect resistant foliage..........-...-

Jersey's Sovereign (Dec.). Salmon orange. A very vigorous grower with dark foliage, which is very resistant to the ravages of the leaf hopper. A splen-

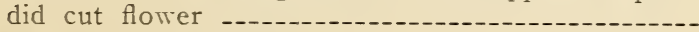

Jersey's Sunshine (Dec.). Light greenish yellow; sometimes streaked Amaranth pink. Flowering habit profuse. Flowers are large and the stems are very stiff and erect 
Jersey's Wonder (Dec. to Peo.). Apricot yellow and Pinard yellow, with a pink suffusion on the reverse. First flowers are Decorated and very large, averaging over 10 inches on good stems; the later flowers are inclined to be Peony, with slightly pendulous stems

Sanhican King (Dec.). Bright, tawny gold, shading to a bronze center; stem slender black and stiff, tall growing plant, excellent keeper when cut

Sanhican Princess (Dec.). Shrimp pink, early and profuse bloomer, medium size, perfectly stiff stems.

Sanhican Gold (Dec.). Pale orange yellow, petals broad at base, terminating in points, stems straight and stiff, dark green foliage

Sanhican Sunrise (Dec.). Evenly placed petals. Orange buff with a rosy hue at the point of the petals. Profuse bloomer, stems black, slender and stiff----

Sanhican Fairy ( $\mathrm{HyCac}$ ). Deep rose pink with about 3 rows of petals in center a deep Tyrian rose. Extremely free bloomer. Dwarf plants, stems slender but stiff

Sanhican Gem (Dec.). Old rose, thickly suffuse amber. Petals are large and thickly places true Staghorn type

Sanhican Magnate (Dec.). Pale Amaranth pink, reverse a solid claret color, heavily veined. One of the largest; free bloomer

Sanhican Monarch (Dec.). Deep Tyrian rose, shaded lighter at tips. A huge deep flower. Dark green foliage. Black cane-like stems. Medium growth. A strictly exhibition flower

Sanhican Ruby (Dec.). Deep shade of pigeon blood suffused bronze. Petals fluffy and pointed; has tremendous size and fine stems

\section{Hickory Hill Dahlia Farm}

301 E. Brookland Boulevard RICHMOND, VIRGINIA.

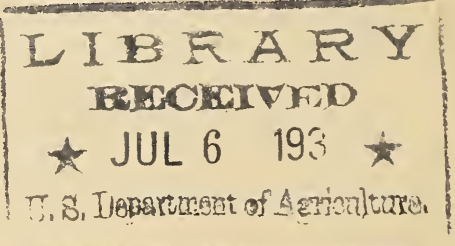


Remittance must accompany order. All retail orders for $\$ 2.00$ or over sent prepaid; on orders for less, add $10 \mathrm{c}$ for postage and packing.

\section{GUARANTEE}

We guarantee tubers true to name as grown by us and free from disease. Beyond this we are not liable and take your order with that understanding. Return tubers to us at once if not satisfactory. Do not wait till Fall or Spring and write us that they did not grow. We positively will not replace a tuber that has not been returned.

Only the best and strongest root divisions are used in filling orders, and the utmost care exercised. But should an error occur, we will gladly rectify it if notified. Most failures in starting roots are due to improper planting or because of attacking insects. No guarantee is given that roots will grow and bloom or will not rot in the ground, as that depends largely on soil, climatic conditions and attention.

Remember that the size of the tuber makes no difference, as a small tuber will give as fine flowers as a large one and in most cases better.

\section{HICKORY HILL DAHLIA FARM,}

By J. S. Bosher. 